\title{
NOTES ON THE SALAMANDERS OF SAN DIEGO COUNTY, CALIFORNIA
}

\author{
By L. M. Klauber
}

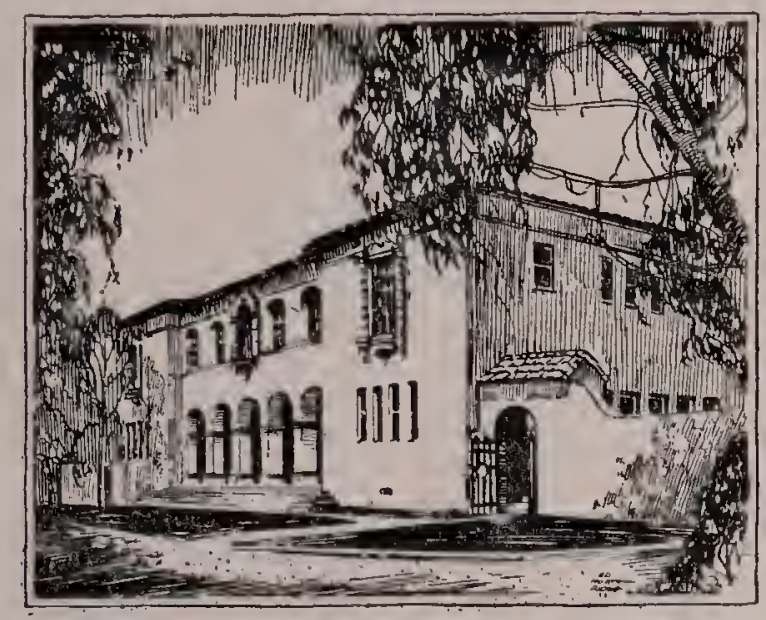

ZOOLOGICAL SOCIETY OF SAN DIEGO

Bulletin No. 3 



\title{
NOTES ON THE SALAMANDERS OF SAN DIEGO COUNTY, CALIFORNIA
}

\author{
By L. M. Klauber
}

Triturus torosus (Eschscholtz)

\section{Pacific Coast Newt}

Orcutt states in the West American Scientist (Vol. I, No. 2, p. 5 , 1885), "The water newts of the falls of the San Diego River, this county, are the 'sad-colored anaides', Anaides lugubris, Hallowell. This is the farthest southern limit of the species known."

Grinnell and Camp assume that Orcutt was referring to Triturus torosus rather than Aneides lugubris lugubris, evidently because the latter is not a "water newt." I am able to confirm this to the extent of stating that Triturus torosus is exceedingly plentiful in Boulder Creek, one of the upper branches of the San Diego River. Here on several occasions large numbers have been taken; 547 were collected on May 16, 1926, at elevation 3670, five and a half miles west of Cuyamaca Reservoir.

\section{Batrachoseps attenuatus leucopus (Dunn)}

\section{Southern Slender Salamander}

This salamander seems to be rather common in moist locations, especially shaded north slopes, throughout the western part of the county. It is frequently found in San Diego (city) gardens. Most of the specimens which I have taken were under stones or boards. I have had specimens from San Diego, La Jolla, Mission Valley, Poway, Spring Valley, Mussey Grade, Wildwood Ranch, Ramona, Descanso, Cottonwood and San Luis Rey River, four miles east of

${ }^{1}$ A Distributional List of the Amphibians and Reptiles of California. Univ. of Cal. Pubs. in Zool., Vol. 17, No. 10, 1917, p. 131. 
Bonsall. Thus, all zones west of the mountains, at least to an altitude of 3450 feet (Descanso) are covered.

The coloration of a live San Diego specimen is not easily described and cannot well be checked by a color chart because of the mottled effect. The general tone is dark brown above with a darker streak on each side followed by a light streak; and a lavender under surface, turning yellowish toward the tail. On close examination the dorsal coloration is seen to be made up of copper-bronze areas having a metallic lustre streaked and mottled with black or dark brown. There are likewise areas and dots of silvery green. The lighter areas on the sides below the dark streaks are the result of a concentration of fine silvery green dots; these, however, do not completely cross the abdominal surface, the central area of which is transparent lavender. These brighter colors tend to disappear in preserved specimens leaving a dorsal brown, and a yellow or buff under surface.

These color notes may be of some interest in connection with the relationship of the San Diego County specimens to those found in other California locations and on Los Coronados Islands.

An unusually large individual of this species measured $127 \mathrm{~mm}$. (5 in.) over all, the tail length being $83 \mathrm{~mm}$. (31/4 in.).

\section{Ensatina croceater (Cope)}

\section{Yellow Spotted Salamander}

The occurrence of Ensatina croceater in Southern California and Lower California has been the subject of discussion and uncertainty. Lockington" (identification by Cope) records it from "a district about seventy-five miles southeast of San Diego."

Cope ${ }^{3}$ mentions a specimen from Cape San Lucas as well as another "from near San Diego" which latter probably refers to the Lockington specimen.

Van Denburgh ${ }^{4}$ considers that these two localities lack confirmation, as does likewise Storer".

${ }^{2}$ List of Californian Reptiles and Batrachians collected by Mr. Dunn .... in 1876. The American Naturalist, April, 1880, p. 295.

${ }^{3}$ The Batrachia of North America. Bull. U. S. N. M. No. 34, 1889, p. 150.

${ }^{4}$ Four Species of Salamand rs, etc. Proc. Cal. Acad. Sci., Fourth Ser., Vol. 6, No. 7, 1916, p. 220.

${ }^{5}$ A Synopsis of the Amphibia of California. Univ. of Cal. Pubs. in Zool., Vol. 27, 1925 , p. 104. 


\section{Klauber-Salamanders of San Diego County}

Dunn" states "I am strongly of the opinion that this form is confined to the Sierra Nevada" and "Probably Lockington's specimen came from the San Pedro Martir Mountains and was eschscholtzii."

I am able to state definitely that $E$. croceater does occur in San Diego County and therefore far to the south of the Sierra Nevada locations heretofore considered the most southerly verified points.

In the Museum of the San Diego Natural History Society there are two specimens collected "under a log" in the Cuyamaca Mountains, San Diego County, May 22, 1917, by C. R. Orcutt. These two specimens are immature. The locality reference is rather indefinite and might mean any point in the vicinity of Cuyamaca Peak from Julian south to Descanso.

October 5, 1925, I received a tailless specimen collected by William Adams at Rose Mine, about one mile northwest of the Big Laguna, in the Laguna Mountains. This location is 42 miles (in a direct line) east of San Diego. The specimen was found on a wet sack half in and half out of water.

January 12, 1927, I received a mature specimen collected in leaf mold by William E. Grant, three miles northeast of Descanso, at elevation 3700 (Fig 1). A juvenile specimen was taken at Descanso, February 22, 1927.

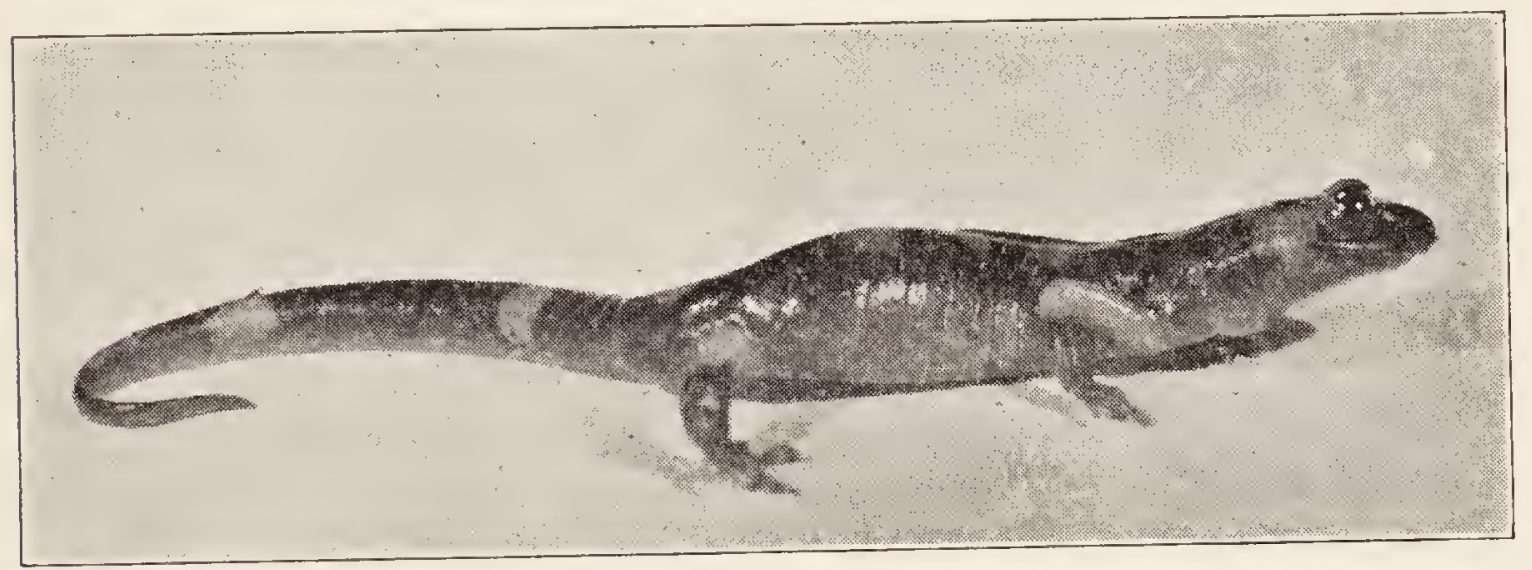

(Figure 1)

Yellow Spotted Salamander (Ensatina croceater) Collected at Descanso. Photo by J. R. Slevin.

As the color descriptions which have appeared seem to be based on alcoholic specimens, the following notes on the Grant specimen while

${ }^{6}$ The Salamanders of the Family Plethodontidae, 1926, p. 185. 
alive, may be of interest. Dorsal color black, fading on the sides to Dusky Purplish Gray". The irregular series of dorsal blotches (one on the head engaging the eyelids, four on the body, four on the tail) are Orange Rufous; under surfaces transparent Light Vinaceous Lilac. The legs are of the same color as the dorsal blotches except the extremities, which are similar to the under surface. The largest dorsal blotch is about $5 \mathrm{~mm}$. by $10 \mathrm{~mm}$. The overall length of this specimen is $140 \mathrm{~mm} .(51 / 2 \mathrm{in}$.)

There are two other specimens in the collection of the San Diego Natural History Society taken in the San Jacinto Mountains, Riverside County, at elevation 5500 feet, April 27, 1903, by Frank Stephens.

The Laguna specimen tends to verify the Lockington specimen as Ensatina croceater, although I would hardly place the locality as far as the San Pedro Martirs, which are 140 miles southeast of San Diego in a direct line. The region of Laguna Hanson, distant 77 miles, would seem a more probable locality. The five San Diego County specimens thus far recorded are from the Transition Zone or closely adjacent areas of the Upper Sonoran.

\section{Aneides lugubris lugubris (Hallowell)}

\section{Arboreal Salamander}

This species must be relatively rare in San Diego County. No specimen has been brought to the Natural History Society or the Zoological Society during the past five years. It has been taken at Sequoia Mine (on Barber Mountain, three miles west of Barrett Dam), and on Sorrento Mountain near La Jolla". "The falls of the San Diego River" record, often listed as a locality record, probably refers to Triturus torosus, as noted above.

'Capitalized colors refer to plates in Ridgway, Color Standards, 1912.

"Frank Stephens. An Annotated List of the Amphibians and Reptiles of San Diego County, California. Trans. S. D. Soc. Nat. Hist., Vol. 3, No. 4, 1921 , p. 59. 
